\title{
Passive Data Use for Ethical Digital Public Health Surveillance in a Postpandemic World
}

John L Kilgallon ${ }^{1,2^{*}}$, BA; Ishaan Ashwini Tewarie ${ }^{1,3,4,5^{*}}$, MD; Marike L D Broekman ${ }^{1,4,5}$, MD, JD, PhD; Aakanksha Rana $^{1,6}, \mathrm{PhD}$; Timothy R Smith ${ }^{1}$, MD, MPH, PhD

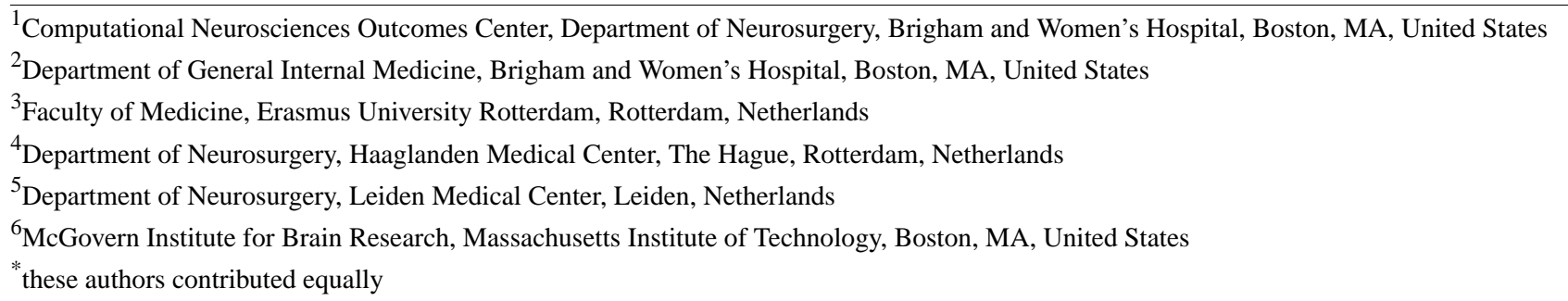

Corresponding Author:

John L Kilgallon, BA

Computational Neurosciences Outcomes Center

Department of Neurosurgery

Brigham and Women's Hospital

75 Francis Street

Boston, MA, 02115

United States

Phone: 19145395441

Email: jkilgallon@bwh.harvard.edu

\section{Abstract}

There is a fundamental need to establish the most ethical and effective way of tracking disease in the postpandemic era. The ubiquity of mobile phones is generating large amounts of passive data (collected without active user participation) that can be used as a tool for tracking disease. Although discussions of pragmatism or economic issues tend to guide public health decisions, ethical issues are the foremost public concern. Thus, officials must look to history and current moral frameworks to avoid past mistakes and ethical pitfalls. Past pandemics demonstrate that the aftermath is the most effective time to make health policy decisions. However, an ethical discussion of passive data use for digital public health surveillance has yet to be attempted, and little has been done to determine the best method to do so. Therefore, we aim to highlight four potential areas of ethical opportunity and challenge: (1) informed consent, (2) privacy, (3) equity, and (4) ownership.

(J Med Internet Res 2022;24(2):e30524) doi: 10.2196/30524

\section{KEYWORDS}

passive data; public health surveillance; digital public health surveillance; pandemic response; data privacy; digital phenotyping; smartphone; mobile phone; mHealth; digital health; informed consent; data equity; data ownership

\section{Background}

In the wake of the COVID-19 pandemic, a more effective and ethically sound system for tracking disease is necessary. In recent years, due to their ubiquity, mobile phones - and the data they collect - have become a potential tool for tracking disease on a broad scale. These devices generate massive amounts of passive data, or information collected without the active participation of the user [1]. However, the current utilization of these data for public health crises is limited; such data are predominantly used for basic contact tracing via Bluetooth or GPS [2]. Emerging technologies, such as digital phenotyping, defined as moment-by-moment quantification of the individual-level human phenotype in situ using data from personal digital devices, allow for continuous monitoring of individuals' health, which has previously been impossible [3]. Attempts to employ these data for digital public health surveillance, defined as "ongoing systematic collection, analysis, and interpretation of data [not generated with the primary goal of surveillance], integrated with the timely dissemination of these data to those who can undertake effective prevention and 
control activities," are currently being undertaken; public health officials must look to history and current moral frameworks to avoid past mistakes and ethical pitfalls [4,5]. Thus, this viewpoint uses a scoping literature review and novel arguments to aid policy makers in critically analyzing how passive data might be used for digital public health surveillance ethically, with a particular focus on lessons to be learned from history.

\section{A Historical Perspective on Surveillance: Proactive Versus Reactive Interventions}

In 1854, John Snow laid the groundwork for modern epidemiology by disabling a cholera-contaminated water pump in Soho, London. By saving lives, Snow's experiment and subsequent health policy advances promoting hygiene demonstrated the fundamental need for proactive public health intervention in times of crisis [6]. Conversely, during the 1918 influenza pandemic, governments met the disease with deliberate ignorance [7]. Death tolls rose to 50 million worldwide, and citizens were forced to implement makeshift systems of social distancing, such as mask wearing and displaying anti-spitting signs $[8,9]$. The disjointed nature of the response is characteristic of the reactive approach; without unified guidelines, decided upon beforehand, citizens are left with little framework on which to base their decisions [10]. A juxtaposition can be found in the 2003 severe acute respiratory syndrome (SARS) epidemic. Although heavily affected countries developed protocols from which they have benefitted during the COVID-19 pandemic, the United States did not face the direct effects of SARS, resulting in very few steps being undertaken to prepare for future outbreaks [11-13]. Likewise, citizens in SARS-affected countries were more willing to adhere to interventions [13]. Operating with preordained protocols, these SARS-affected countries found far greater early success against COVID-19.

Pandemic response progress has fluctuated based on contemporary national politics, social norms, and the scientific understanding of diseases through history [14]. Generally, examples of health crises demonstrate that coordinated surveillance by officials and public adherence to guidelines are integral to limiting disease spread (Figure 1) [15-23]. This must be kept in mind when turning toward the future to maximize the impact of emerging technologies such as digital phenotyping for health surveillance systems. Now is the time to make policy decisions, as the choices made about passive data use for digital public health surveillance in the years following the COVID-19 pandemic have the potential to impact our lives profoundly. Although discussions of pragmatism or economic issues tend to guide digital public health surveillance decisions, ethical questions of informed consent, data privacy, data equity, and data ownership are the foremost public concerns; a consequence of not addressing these issues is eroding trust in governmental institutions and science [24]. Surveillance measures, therefore, must be functional and within ethical guidelines.

Figure 1. A timeline of modern public health advances, technological innovations, and pandemics and disease outbreaks. MERS: Middle East respiratory syndrome; SARS: severe acute respiratory syndrome: UN: United Nations.

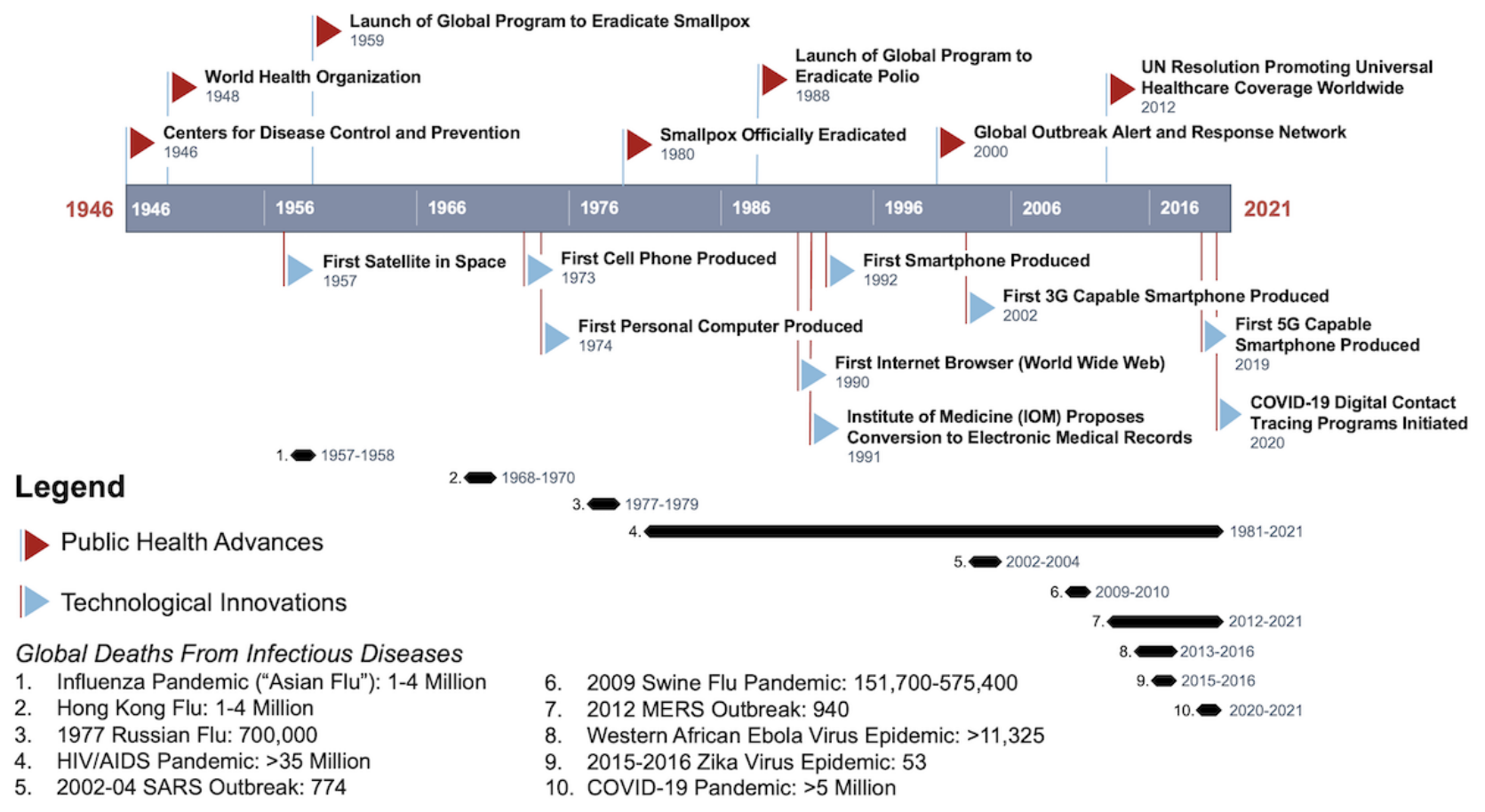

\section{Passive Data: Pandemic Surveillance Pearls and Promises}

The momentum of technological innovations has inspired a new age of digital solutions in public health. In 2014, the number of mobile phone subscriptions surpassed the number of people on the planet $(\sim 7.2$ billion), illustrating a new parity between humans and devices on which policies could capitalize [3]. Early in the pandemic, governments and technology corporations deployed contact-tracing systems using Bluetooth interactions widely [2]. However, this type of solution is limited; it is 
reactive, only applicable after disease transmission has likely already occurred.

Recent innovations in using passive data, such as digital phenotyping, have the potential to measure a subject's physical and mental well-being and will allow for a far more accurate level of surveillance [3]. Passive data encompass various streams, including GPS, accelerometer, text, and call log data, and have been employed in a wide range of clinical settings, from monitoring spinal surgery patients' recoveries to tracking relapses in patients with schizophrenia [25-37]. The significant benefits of using passive data for digital public health surveillance include the data's objectivity, quantifiability, and continuous nature [1]. This contrasts with the use of active data, such as patient-reported outcome measures, which rely on subjective measurements that are harder to quantify accurately [1]. The sophisticated analysis of passive data for digital public health surveillance has yet to be attempted on a large scale, however, and there is no academic consensus on how best to do so [38-40]. Thus, this paper puts forth four challenges that must be addressed when considering the ethics of digital public health surveillance: (1) the level of transparency during the consent process (informed consent), (2) the anonymity and security measures taken to protect the data (privacy), (3) the equitable distribution of benefit from digital public health surveillance (equity), and (4) the determination of who has rights to the data (ownership; Figure 2) [24].

Figure 2. Goals for ethical passive data public health surveillance.

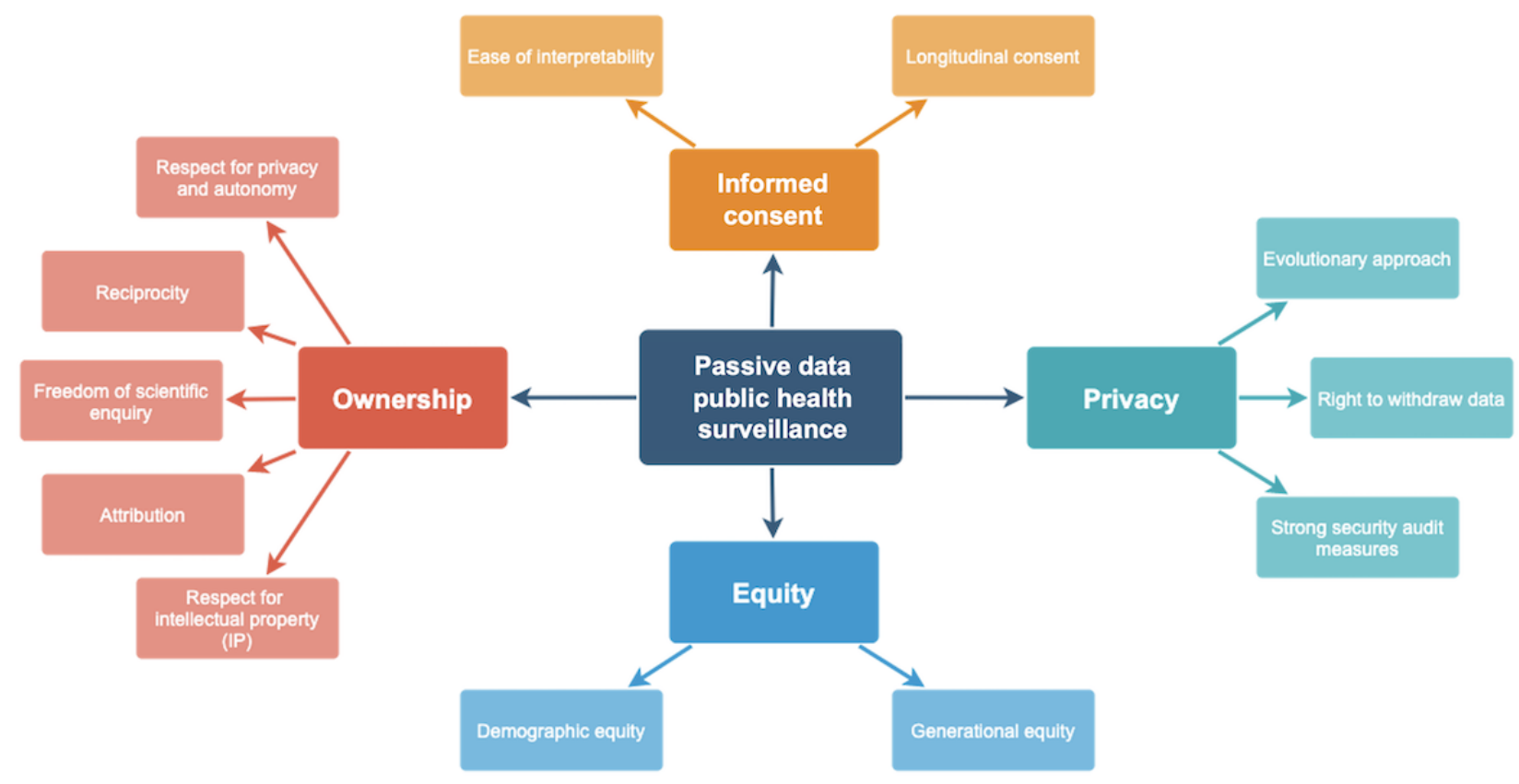

\section{Informed Consent}

Confirming that the public genuinely provides informed consent becomes challenging as information is increasingly digitized. The platform for medical surveillance has moved from controlled (eg, doctors' offices) to uncontrolled (eg, smartphones) environments. In examining the challenges of gaining patients' permission to use their data, two main pillars arise: (1) ease of interpretability and (2) longitudinal consent. Trust between officials and the public can be maintained as long as the information provided is understandable and interpretable. Levels of patient comprehension comparable to current consent procedures are attainable through mobile health consenting programs, assuming care is taken to design the interface intuitively [41]. Tools such as social annotations, live feedback, and visual aids have been suggested to help accomplish this goal $[1,41,42]$. However, there is little evidence to show that no current method of consenting patients achieves adequate patient comprehension [43]. Customizable, interactive, and educational consent forms to be evaluated on the patients' own time, rather than in person, would help to streamline the process and relieve stress on both sides [44,45]. Likewise, it would allow for greater regulation of bias on the part of the provider, which has been shown to play a role in patients' ability to give consent freely [46].

The perpetuity of consent has also come into question, as the technology used is inherently complex and often outside of patients' or providers' realms of expertise [47]. Therefore, the growth of digital public health surveillance could entail a move from the current practice of a "consent or anonymize" approach to one of "consent for governance" [1]. Under the former, the patient gives "broad consent" under the assumption that data will be implemented later using pseudonymization; this allows patients no long-term rights to their data. Conversely, the latter incorporates the context in which an entity hopes to use the data, making it conditional. Thus, gaining initial patient consent does not guarantee longitudinal ethical viability. A continued effort to maintain a reliable open source of information for patients is necessary.

\section{Privacy}

Experts note five distinct threats to data privacy under digital surveillance: the invisibility, inaccuracy, immortality, 
marketability, and identifiability of data [48]. Given this, we put forth three main pillars to be upheld in maintaining data privacy: (1) an evolutionary approach, (2) the right to withdraw data, and (3) strong security audit measures. Authorities remark that if surveillance practices currently being conducted digitally were carried out in person (eg, a third party reading patients' text messages and following them from location to location), rather than invisibly, it would be unacceptable [48], yet this level of observation would be inherent to digital public health surveillance systems. Further, machines interpret data literally; therefore, the analysis of specific actions (eg, unknowingly dropping one's phone on the street) through passive data could lead to inaccurate conclusions (eg, a traumatic fall requiring emergency medical services) [48]. Third, researchers note that the immortality of data inevitably results in elevated risk, as even the lowest possible risk over an extended period translates to high overall risk [48]. The marketability of data is also a concern, as it is the entities that collect the data (institutions), not those that generate the data (patients) that are currently compensated, creating an incentive for unethical practices [48]. Finally, it has been demonstrated that anonymized patient data can be reidentified using machine learning [49]. Thus, the identifiability of the data could have wide-ranging consequences, from fostering attempts to shape political opinions based on one's health profile to allowing one's prognosis to have an impact on their ability to be hired [48].

Innovative multisectoral approaches will be needed going forward to prevent breaches and maintain requisite data privacy and security. The Health Insurance Portability and Accountability Act (HIPAA) in the United States and the new General Data Protection Regulation (GDPR) in the European Union were enacted to ensure legal repercussions for those who break data confidentiality. However, in the digital age, it has been posited that all data can be used as health data [48]. Likewise, as these regulations only apply to personal health information in its traditional form, they have become inadequate and outdated. Digital public health surveillance systems must continually be refined to incorporate the idiosyncrasies involved in in vivo health surveillance. Current efforts to accomplish this goal include innovations such as the cryptographic and differential privacy approach, which makes patient data less recognizable and reidentifiable, as well as federated learning, which promotes the idea of building systems without any data sharing [50]. Additionally, individuals must be allowed the right to request deletion of their health data at any time and for any reason to restrict data perpetuity. Strong privacy and security audit policies must become commonplace, as complacency with security measures could lead to areas of weakness to be exploited. Furthermore, continuous communication from the entities storing the data of its security and trustworthiness will be necessary, so as not to foster a "generalization of suspicion," where patients feel as though they are guilty until proven innocent [51].

\section{Equity}

In recent history, the unchecked or blind usage of innovative technologies has exacerbated existing health care inequalities, reflected in the form of biased data, such as the own-race bias phenomenon in facial recognition [52]. Passive data-driven solutions, then, should be thought of as tools that could reduce disparities by widening access to public health surveillance, but only if implemented mindfully, as it is unclear which subpopulations are truly at the greatest risk of these health inequities [1,53]. To ensure fairness in passive data use, a balance must be struck between two principles: (1) demographic equity and (2) generational equity. Low socioeconomic status populations and people of color are often marginalized and burdened by negative social determinants of health [54]. Passive data can potentially reduce health inequities for these populations, as conventional determinants such as lack of insurance and access to health care facilities could theoretically be circumvented [54-56]. In 2019, smartphone ownership was fairly consistent across races, with $82 \%$ of White people, $80 \%$ of Black people, and $79 \%$ of Hispanic people owning a smartphone, compared to more variable health care coverage status $(92.2 \%, 90.4 \%$, and $83.3 \%$, respectively) [57,58]. Passive data use also has the potential to improve digital public health surveillance globally, as smartphone ownership in low- and middle-income countries (LMICs) continues to increase rapidly. In 2019, the median smartphone ownership was $45 \%$ in emerging economies, up from $37 \%$ in 2015 [59,60]. In LMICs, where access to adequate health care can be scarce, strengthening access to these technologies could be a viable supplement.

However, unrestrained use of technology in passive data collection and analysis could also introduce health inequities such as preventing those without technological access or with physical, age-related, disease-related, or mental impairments from receiving equitable care [61]. One population that might be left behind by increased digital public health surveillance is older adults. Although all US adults older than 65 years have access to health coverage through Medicare, only 55\% owned a smartphone in 2019 [57,58]. Potential solutions to generational inequities include working with manufacturers to design digital public health surveillance technology and services keeping in mind how older populations specifically might perceive and use them, as well as implementing optimized plans and models to provide all people with affordable high-speed internet access. Overall, disparities in technological access both in the United States and globally must be tracked and actively combatted if digital public health surveillance systems are to provide equitable levels of care across demographics and generations.

\section{Ownership}

Though there is no current consensus on how best to address passive data storage and ownership issues, experts have put forth potential solutions. The majority of these involve policy interventions to restrict single institutions from monopolizing databases [39]. For example, some suggest public policy to create networks of patients with data sharing responsibility. In contrast, others promote policies that consider the rights to one's health data to be civil liberty $[39,62,63]$. Another possible solution that has gained traction is a paradigm shift in governing data access from ownership to custodianship [64]. This aligns with the theory that big data cannot be "owned" in a traditional sense, but instead should be guarded and overseen [64]. For this 
new structure to be viable, five principles must be upheld: (1) respect for privacy and autonomy, (2) reciprocity, (3) freedom of scientific enquiry, (4) attribution, and (5) respect for intellectual property (IP) [64]. Under this system, a balance must be struck between confidentiality and accountability, as institutions (or custodians) of the data must keep the identities of the subjects (or donors) private while also remaining beholden to them. Likewise, custodians must also be forthcoming with their findings and metadata, just as donors are with the original passive health data. Health data should be used solely for the common good, as its value makes it a target to be bought and sold by bad actors [64]. Lastly, proper credit and respect for IP will reduce the restriction of access to databases by ensuring that the sacrifices made by both donor and custodian are appreciated. These data-sharing agreements are made fittingly [64]. Pioneering policy ideas such as these will be necessary if passive data is to be implemented into digital public health surveillance successfully.

Even under the assumption that future frameworks should widen access to these data, some researchers argue for a centralized database, while others support decentralization [39,58]. The latter group argues that patients have little idea of their data's actual value. Systems such as blockchain (ie, a digital record of transactions validated by a peer-to-peer network) could serve to decentralize and better quantify the worth of individuals' health data $[39,65]$. Each proposal has positives and negatives. For example, centralization would increase ease of access but could leave databases more susceptible to large-scale hacks. In addition, although decentralization would allow patients to earn tangible rewards for their data, this could lead to undue influences playing a role in the decision to share one's data $[63,65]$. Coming to a consensus on these issues is one of the most critical next steps for advancing passive data use for digital public health surveillance.

\section{Conclusion: Planning Now for the Future}

The time to plan and prepare for the next pandemic is now. This means coming to terms with the massive potential (for better or worse) of passive data derived from personal digital devices. The potential for success of digital public health surveillance relies on the ethical viability of its implementation. Before the next pandemic, officials must ensure that we are prepared by overhauling current consenting protocols. During the next pandemic, policies must be enacted to account for all possible inequities, while maintaining trust between citizens and institutions. In the wake of the next pandemic, the long-term security of health data must be guaranteed with an assurance that it will not be used for any undue gain. These preparations must be undertaken now, proactively, using the lessons fresh in citizens' collective consciousness. Passive data and methods such as digital phenotyping can serve as the foundation upon which this improved system can be built. However, if done without historical, ethical, and practical considerations, we will be left with even more challenges than we face today.

\section{Authors' Contributions}

JLK, IAT, and AR designed the research. JLK and IAT cowrote the paper. MLDB, AR, and TRS jointly supervised this work. MLDB, AR, and TRS critically revised the paper.

\section{Conflicts of Interest}

None declared.

\section{References}

1. Maher NA, Senders JT, Hulsbergen AFC, Lamba N, Parker M, Onnela J, et al. Passive data collection and use in healthcare: A systematic review of ethical issues. Int J Med Inform 2019 Sep;129:242-247. [doi: 10.1016/j.ijmedinf.2019.06.015] [Medline: 31445262]

2. Zastrow M. Coronavirus contact-tracing apps: can they slow the spread of COVID-19? Nature 2020 May 19. [doi: 10.1038/d41586-020-01514-2] [Medline: 32433633]

3. Onnela J, Rauch SL. Harnessing smartphone-based digital phenotyping to enhance behavioral and mental health. Neuropsychopharmacology 2016 Jun;41(7):1691-1696. [doi: 10.1038/npp.2016.7] [Medline: 26818126]

4. Norbury A, Liu SH, Campaña-Montes JJ, Romero-Medrano L, Barrigón ML, Smith E, MEmind Study Group, et al. Social media and smartphone app use predicts maintenance of physical activity during Covid-19 enforced isolation in psychiatric outpatients. Mol Psychiatry 2020 Dec 14:3920-3930 [FREE Full text] [doi: 10.1038/s41380-020-00963-5] [Medline: 33318619]

5. Shakeri Hossein Abad Z, Kline A, Sultana M, Noaeen M, Nurmambetova E, Lucini F, et al. Digital public health surveillance: a systematic scoping review. NPJ Digit Med 2021 Mar 03;4(1):41 [FREE Full text] [doi: 10.1038/s41746-021-00407-6] [Medline: 33658681$]$

6. Ruths MB. The lesson of john snow and the broad street pump. Virtual Mentor 2009 Jun 01;11(6):470-472 [FREE Full text] [doi: 10.1001/virtualmentor.2009.11.6.mhst1-0906] [Medline: 23199359]

7. Martini M, Gazzaniga V, Bragazzi NL, Barberis I. The Spanish Influenza Pandemic: a lesson from history 100 years after 1918. J Prev Med Hyg 2019 Mar;60(1):E64-E67 [FREE Full text] [doi: 10.15167/2421-4248/jpmh2019.60.1.1205] [Medline: 31041413]

8. Centers for Disease Control and Prevention; 2018. History of 1918 Flu Pandemic. URL: https://www.cdc.gov/flu/ pandemic-resources/1918-commemoration/1918-pandemic-history.htm [accessed 2020-07-17] 
9. Little B. HISTORY. 'Mask Slackers' and 'Deadly' Spit: The 1918 Flu Campaigns to Shame People Into Following New

Rules URL: https://www.history.com/news/1918-pandemic-public-health-campaigns [accessed 2022-02-04]

10. McCullough M. Ethical decision making in a pandemic: where are the voices of vulnerable people? BMJ 2020 Jun 19;369:m2406. [doi: 10.1136/bmj.m2406] [Medline: 32561520]

11. Broder J. The SARS Epidemic: The American Response; Aggressive Steps, and Luck, Help U.S. Avoid SARS Brunt. The New York Times. 2003 May 05. URL: https://www.nytimes.com/2003/05/05/us/ sars-epidemic-american-response-aggressive-steps-luck-help-us-avoid-sars-brunt.html [accessed 2022-02-04]

12. Person B, Sy F, Holton K, Govert B, Liang A, National Center for Inectious Diseases/SARS Community Outreach Team. Fear and stigma: the epidemic within the SARS outbreak. Emerg Infect Dis 2004 Feb;10(2):358-363 [FREE Full text] [doi: 10.3201/eid1002.030750] [Medline: 15030713]

13. Tan KYL. Singapore's Regulatory Response to COVID-19. The Regulatory Review. 2020 Jul 01. URL: https://www. theregreview.org/2020/06/15/tan-singapore-regulatory-response-covid-19/ [accessed 2021-04-15]

14. Institute of Medicine (US). Ethical and Legal Considerations in Mitigating Pandemic Disease. In: National Academies Press (US). 2007 Presented at: Institute of Medicine (US) Forum on Microbial Threats; September 19-20, 2006; Washington, DC. [doi: $10.17226 / 11917$ ]

15. European Centre for Disease Prevention and Control. Geographical distribution of confirmed MERS-CoV cases by country of infection and year. European Union. URL: https://www.ecdc.europa.eu/en/publications-data/ geographical-distribution-confirmed-mers-cov-cases-country-infection-and-year [accessed 2021-04-25]

16. Dawood FS, Iuliano AD, Reed C, Meltzer MI, Shay DK, Cheng P, et al. Estimated global mortality associated with the first 12 months of 2009 pandemic influenza A H1N1 virus circulation: a modelling study. Lancet Infect Dis 2012 Sep;12(9):687-695. [doi: 10.1016/S1473-3099(12)70121-4] [Medline: 22738893]

17. Dong E, Du H, Gardner L. An interactive web-based dashboard to track COVID-19 in real time. Lancet Infect Dis 2020 Feb 19:533-534. [doi: 10.1016/S1473-3099(20)30120-1] [Medline: 32087114]

18. Michaelis M, Doerr HW, Cinatl J. Novel swine-origin influenza A virus in humans: another pandemic knocking at the door. Med Microbiol Immunol 2009 Aug;198(3):175-183. [doi: 10.1007/s00430-009-0118-5] [Medline: 19543913]

19. Pandemic Influenza Risk Management WHO Interim Guidance. World Health Organization. 2013. URL: https://www. who.int/influenza/preparedness/pandemic/GIP PandemicInfluenzaRiskManagementInterimGuidance Jun2013.pdf?ua=1 [accessed 2021-04-25]

20. Summary of probable SARS cases with onset of illness from 1 November 2002 to 31 July 2003. World Health Organization. 2015. URL: https://www.who.int/publications/m/item/ summary-of-probable-sars-cases-with-onset-of-illness-from-1-november-2002-to-31-july-2003 [accessed 2021-04-25]

21. 2015-16 Zika Virus Epidemic. Worldwide Outbreak. URL: https://www.worldwideoutbreak.com/blog/cool timeline/ 2015-16-zika-virus-epidemic/ [accessed 2021-04-25]

22. 2014-2016 Ebola Outbreak in West Africa. Centers for Disease Control and Prevention. 2019. URL: https://www.cdc.gov/ vhf/ebola/history/2014-2016-outbreak/index.html [accessed 2021-04-25]

23. HIV Surveillance Report, 2018 (Updated). Centers for Disease Control and Prevention. URL: http://www.cdc.gov/hiv/ library/reports/hiv-surveillance.html [accessed 2021-04-15]

24. Simon SR, Evans JS, Benjamin A, Delano D, Bates DW. Patients' attitudes toward electronic health information exchange: qualitative study. J Med Internet Res 2009;11(3):e30 [FREE Full text] [doi: 10.2196/jmir.1164] [Medline: 19674960]

25. Aledavood T, Torous J, Triana Hoyos AM, Naslund JA, Onnela J, Keshavan M. Smartphone-based tracking of sleep in depression, anxiety, and psychotic disorders. Curr Psychiatry Rep 2019 Jun 04;21(7):49 [FREE Full text] [doi: 10.1007/s11920-019-1043-y] [Medline: 31161412]

26. Barnett I, Onnela J. Inferring mobility measures from GPS traces with missing data. Biostatistics 2020 Apr 01;21(2):e98-e112. [doi: 10.1093/biostatistics/kxy059] [Medline: 30371736]

27. Barnett I, Torous J, Staples P, Keshavan M, Onnela J. Beyond smartphones and sensors: choosing appropriate statistical methods for the analysis of longitudinal data. J Am Med Inform Assoc 2018 Dec 01;25(12):1669-1674. [doi: 10.1093/jamia/ocy121] [Medline: $\underline{30272176}$ ]

28. Barnett I, Torous J, Staples P, Sandoval L, Keshavan M, Onnela J. Relapse prediction in schizophrenia through digital phenotyping: a pilot study. Neuropsychopharmacology 2018 Jul;43(8):1660-1666. [doi: 10.1038/s41386-018-0030-z] [Medline: 29511333]

29. Berry JD, Paganoni S, Carlson K, Burke K, Weber H, Staples P, et al. Design and results of a smartphone-based digital phenotyping study to quantify ALS progression. Ann Clin Transl Neurol 2019 May;6(5):873-881 [FREE Full text] [doi: 10.1002/acn3.770] [Medline: 31139685$]$

30. Beukenhorst AL, Collins E, Burke KM, Rahman SM, Clapp M, Konanki SC, et al. Smartphone data during the COVID-19 pandemic can quantify behavioral changes in people with ALS. Muscle Nerve 2021 Feb;63(2):258-262 [FREE Full text] [doi: 10.1002/mus.27110] [Medline: $\underline{33118628]}$

31. Cote DJ, Barnett I, Onnela J, Smith TR. Digital phenotyping in patients with spine disease: A novel approach to quantifying mobility and quality of life. World Neurosurgery 2019 Jun;126:e241-e249. [doi: 10.1016/j.wneu.2019.01.297] 
32. Panda N, Solsky I, Huang EJ, Lipsitz S, Pradarelli JC, Delisle M, et al. Using smartphones to capture novel recovery metrics after cancer surgery. JAMA Surg 2020 Feb 01;155(2):123-129 [FREE Full text] [doi: 10.1001/jamasurg.2019.4702] [Medline: 31657854$]$

33. Staples P, Torous J, Barnett I, Carlson K, Sandoval L, Keshavan M, et al. A comparison of passive and active estimates of sleep in a cohort with schizophrenia. NPJ Schizophr 2017 Oct 16;3(1):37 [FREE Full text] [doi: 10.1038/s41537-017-0038-0] [Medline: 29038553]

34. Torous J, Kiang MV, Lorme J, Onnela J. New tools for new research in psychiatry: a scalable and customizable platform to empower data driven smartphone Research. JMIR Ment Health 2016;3(2):e16 [FREE Full text] [doi: 10.2196/mental.5165] [Medline: 27150677]

35. Torous J, Onnela J, Keshavan M. New dimensions and new tools to realize the potential of RDoC: digital phenotyping via smartphones and connected devices. Transl Psychiatry 2017 Dec 07;7(3):e1053 [FREE Full text] [doi: 10.1038/tp.2017.25] [Medline: 28267146]

36. Torous J, Staples P, Barnett I, Sandoval LR, Keshavan M, Onnela J. Characterizing the clinical relevance of digital phenotyping data quality with applications to a cohort with schizophrenia. NPJ Digit Med 2018;1:15 [FREE Full text] [doi: 10.1038/s41746-018-0022-8] [Medline: 31304300]

37. Torous J, Staples P, Onnela J. Realizing the potential of mobile mental health: new methods for new data in psychiatry. Curr Psychiatry Rep 2015 Aug;17(8):602. [doi: 10.1007/s11920-015-0602-0] [Medline: 26073363]

38. Hand DJ. Aspects of data ethics in a changing world: where are we now? Big Data 2018 Sep 01;6(3):176-190 [FREE Full text] [doi: 10.1089/big.2018.0083] [Medline: 30283727]

39. Mirchev M, Mircheva I, Kerekovska A. The academic viewpoint on patient data ownership in the context of big data: scoping review. J Med Internet Res 2020 Aug 18;22(8):e22214. [doi: 10.2196/22214] [Medline: 32808934]

40. Mittelstadt BD, Floridi L. The ethics of big data: current and foreseeable issues in biomedical contexts. Sci Eng Ethics 2016 Apr;22(2):303-341. [doi: 10.1007/s11948-015-9652-2] [Medline: 26002496]

41. Iwaya LH, Li J, Fischer-Hübner S, Åhlfeldt R, Martucci LA. E-consent for data privacy: consent management for mobile health technologies in public health surveys and disease surveillance. Stud Health Technol Inform 2019 Aug 21;264:1223-1227. [doi: 10.3233/SHTI190421] [Medline: $\underline{\text { 31438120] }}$

42. Chen C, Lee P, Pain KJ, Delgado D, Cole CL, Campion TR. Replacing paper informed consent with electronic informed consent for research in academic medical centers: a scoping review. AMIA Jt Summits Transl Sci Proc 2020;2020:80-88 [FREE Full text] [Medline: 32477626]

43. Agozzino E, Borrelli S, Cancellieri M, Carfora FM, Di Lorenzo T, Attena F. Does written informed consent adequately inform surgical patients? A cross sectional study. BMC Med Ethics 2019 Jan 07;20(1):1 [FREE Full text] [doi: 10.1186/s12910-018-0340-z] [Medline: $\underline{\text { 30616673] }}$

44. Harle CA, Golembiewski EH, Rahmanian KP, Krieger JL, Hagmajer D, Mainous AG, et al. Patient preferences toward an interactive e-consent application for research using electronic health records. J Am Med Inform Assoc 2018 Mar 01;25(3):360-368 [FREE Full text] [doi: 10.1093/jamia/ocx145] [Medline: 29272408]

45. Skelton E, Drey N, Rutherford M, Ayers S, Malamateniou C. Electronic consenting for conducting research remotely: A review of current practice and key recommendations for using e-consenting. Int J Med Inform 2020 Nov;143:104271 [FREE Full text] [doi: 10.1016/j.ijmedinf.2020.104271] [Medline: $\underline{\text { 32979650] }}$

46. Hall DE, Prochazka AV, Fink AS. Informed consent for clinical treatment. CMAJ 2012 Mar 20;184(5):533-540 [FREE Full text] [doi: 10.1503/cmaj.112120] [Medline: 22392947]

47. Helgesson G, Ludvigsson J, Gustafsson Stolt U. How to handle informed consent in longitudinal studies when participants have a limited understanding of the study. J Med Ethics 2005 Nov;31(11):670-673 [FREE Full text] [doi: 10.1136/jme.2004.009274] [Medline: 16269567]

48. Grande D, Luna Marti X, Feuerstein-Simon R, Merchant RM, Asch DA, Lewson A, et al. Health policy and privacy challenges associated with digital technology. JAMA Netw Open 2020 Jul 01;3(7):e208285 [FREE Full text] [doi: 10.1001/jamanetworkopen.2020.8285] [Medline: 32644138]

49. Na L, Yang C, Lo C, Zhao F, Fukuoka Y, Aswani A. Feasibility of reidentifying individuals in large national physical activity data sets from which protected health information has been removed with use of machine learning. JAMA Netw Open 2018 Dec 07;1(8):e186040 [FREE Full text] [doi: 10.1001/jamanetworkopen.2018.6040] [Medline: 30646312]

50. Kaissis GA, Makowski MR, Rückert D, Braren RF. Secure, privacy-preserving and federated machine learning in medical imaging. Nat Mach Intell 2020 Jun 08;2(6):305-311. [doi: 10.1038/s42256-020-0186-1]

51. Samerski S. Individuals on alert: digital epidemiology and the individualization of surveillance. Life Sci Soc Policy 2018 Jun 14;14(1):13 [FREE Full text] [doi: 10.1186/s40504-018-0076-z] [Medline: 29900518]

52. Wong HK, Stephen ID, Keeble DRT. The own-race bias for face recognition in a multiracial society. Front Psychol 2020;11:208 [FREE Full text] [doi: 10.3389/fpsyg.2020.00208] [Medline: 32210861]

53. Obermeyer Z, Powers B, Vogeli C, Mullainathan S. Dissecting racial bias in an algorithm used to manage the health of populations. Science 2019 Oct 25;366(6464):447-453. [doi: 10.1126/science.aax2342] [Medline: 31649194]

54. Braveman P, Gottlieb L. The social determinants of health: it's time to consider the causes of the causes. Public Health Rep 2014;129 Suppl 2:19-31 [FREE Full text] [doi: 10.1177/00333549141291S206] [Medline: 24385661] 
55. Armstrong K, Ravenell KL, McMurphy S, Putt M. Racial/ethnic differences in physician distrust in the United States. Am J Public Health 2007 Jul;97(7):1283-1289. [doi: 10.2105/AJPH.2005.080762] [Medline: 17538069]

56. Scharff DP, Mathews KJ, Jackson P, Hoffsuemmer J, Martin E, Edwards D. More than Tuskegee: understanding mistrust about research participation. J Health Care Poor Underserved 2010 Aug;21(3):879-897 [FREE Full text] [doi: 10.1353/hpu.0.0323] [Medline: 20693733]

57. Mobile Fact Sheet. Pew Research Center. URL: https://www.pewresearch.org/internet/fact-sheet/mobile/ [accessed 2021-04-15]

58. Keisler-Starkey K, Bunch L. Health Insurance Coverage in the United States. Washington, DC: U.S. Census Bureau; 2021 Sep 14. URL: https://www.census.gov/library/publications/2020/demo/p60-271.html [accessed 2022-02-04]

59. Poushter J. Smartphone Ownership and Internet Usage Continues to Climb in Emerging Economies. Pew Research Center. 2016. URL: https://www.pewresearch.org/global/2016/02/22/

smartphone-ownership-and-internet-usage-continues-to-climb-in-emerging-economies/ [accessed 2021-04-15]

60. Silver L. Smartphone Ownership Is Growing Rapidly Around the World, but Not Always Equally. Pew Research Center. 2019. URL: https://www.pewresearch.org/global/2019/02/05/ smartphone-ownership-is-growing-rapidly-around-the-world-but-not-always-equally/ [accessed 2021-04-15]

61. Eruchalu CN, Pichardo MS, Bharadwaj M, Rodriguez CB, Rodriguez JA, Bergmark RW, et al. The expanding digital divide: digital health access inequities during the COVID-19 pandemic in New York City. J Urban Health 2021 Apr;98(2):183-186 [FREE Full text] [doi: 10.1007/s11524-020-00508-9] [Medline: 33471281]

62. Heitmueller A, Henderson S, Warburton W, Elmagarmid A, Pentland AS, Darzi A. Developing public policy to advance the use of big data in health care. Health Aff (Millwood) 2014 Sep;33(9):1523-1530. [doi: 10.1377/hlthaff.2014.0771] [Medline: 25201656]

63. Kish LJ, Topol EJ. Unpatients-why patients should own their medical data. Nat Biotechnol 2015 Sep;33(9):921-924. [doi: 10.1038/nbt.3340] [Medline: 26348958]

64. Ballantyne A. How should we think about clinical data ownership? J Med Ethics 2020 May;46(5):289-294. [doi: 10.1136/medethics-2018-105340] [Medline: 31911499]

65. Mamoshina P, Ojomoko L, Yanovich Y, Ostrovski A, Botezatu A, Prikhodko P, et al. Converging blockchain and next-generation artificial intelligence technologies to decentralize and accelerate biomedical research and healthcare. Oncotarget 2018 Jan 19;9(5):5665-5690 [FREE Full text] [doi: 10.18632/oncotarget.22345] [Medline: 29464026]

\author{
Abbreviations \\ GDPR: General Data Protection Regulation \\ HIPAA: Health Insurance Portability and Accountability Act \\ IP: intellectual property \\ LMIC: low- and middle-income country \\ SARS: severe acute respiratory syndrome
}

Edited by A Mavragani; submitted 18.05.21; peer-reviewed by Z Shakeri, H Jarke, I Mircheva; comments to author 20.07.21; revised
version received 14.09.21; accepted 30.11.21; published 15.02 .22
Please cite as:
Kilgallon JL, Tewarie IA, Broekman MLD, Rana A, Smith TR
Passive Data Use for Ethical Digital Public Health Surveillance in a Postpandemic World
J Med Internet Res 2022;24(2):e30524
URL: $\underline{\text { https://www.jmir.org/2022/2/e30524 }}$
doi: $\underline{10.2196 / 30524}$
PMID:

CJohn L Kilgallon, Ishaan Ashwini Tewarie, Marike L D Broekman, Aakanksha Rana, Timothy R Smith. Originally published in the Journal of Medical Internet Research (https://www.jmir.org), 15.02.2022. This is an open-access article distributed under the terms of the Creative Commons Attribution License (https://creativecommons.org/licenses/by/4.0/), which permits unrestricted use, distribution, and reproduction in any medium, provided the original work, first published in the Journal of Medical Internet Research, is properly cited. The complete bibliographic information, a link to the original publication on https://www.jmir.org/, as well as this copyright and license information must be included. 